\title{
PENINGKATAN KEMAMPUAN MENULIS ARTIKEL ILMIAH MELALUI STRATEGI PEMBELAJARAN BERBASIS KECERDASAN VERBAL LINGUISTIK
}

\author{
Sabitul Kirom \\ Universitas Islam Balitar Blitar \\ Jalan Majapahit 4A Kota Blitar, 66137, Indonesia \\ Email: sabitulkirom@gmail.com
}

\begin{abstract}
Abstrak
Keterampilan menulis artikel ilmiah merupakan keterampilan yang penting dikuasai oleh setiap mahasiswa. Kegiatan menulis artikel ilmiah menjadi sarana dalam melatih kemampuan mahasiswa dalam mengomunikasikan hasil pemikiran maupun penelitian yang dilakukan. Namun, kenyataannya mahasiswa banyak yang mengalami kesulitan dalam menulis artikel ilmiah. Penelitian ini bertujuan untuk meningkatkan kemampuan mahasiswa dalam menulis artikel ilmiah melalui strategi pembelajaran berbasis kecerdasan verbal linguistik. Penelitian yang dilakukan ini menggunakan pendekatan kualitatif dengan desain Penelitian Tindakan Kelas. Data yang digunakan dalam penelitian berupa data proses dan data produk pembelajaran menulis artikel ilmiah menggunakan strategi pembelajaran berbasis kecerdasan verbal linguistik. Hasil penelitian ini menunjukkan bahwa kemampuan mahasiswa dalam menulis artikel ilmiah dapat ditingkatkan melalui strategi pembelajaran berbasis kecerdasan verbal linguistik. Peningkatan kemampuan mahasiswa tersebut dapat dilihat dari segi proses maupun produk hasil pembelajaran.
\end{abstract}

Kata kunci: kemampuan menulis artikel ilmiah, strategi kecerdasan verbal linguistik

\section{IMPROVEMENT OF SCIENTIFIC WRITING ARTICLES THROUGH LINGUISTIC VERBAL INTELLIGENCE LEARNING STRATEGY}

\begin{abstract}
The skill of writing scientific articles is an important skill mastered by every student. The activity of writing scientific articles becomes a means in training students' abilities in communicating the results of their thoughts and research. However, in reality, many students have difficulty in writing scientific articles. This study aims to improve students' abilities in writing scientific articles through learning strategies based on verbal-linguistic intelligence. This research uses a qualitative approach with the Classroom Action Research design. The data used in this research are process data and learning product data writing scientific articles using learning strategies based on verbal-linguistic intelligence. The results of this study indicate that students' abilities in writing scientific articles can be improved through learning strategies based on verbal-linguistic intelligence. Improvement of student ability can be seen in terms of the process and product of learning outcomes.
\end{abstract}

Keywords: the ability to write scientific articles, linguistic verbal intelligence strategies 


\section{A. Pendahuluan}

Keterampilan menulis merupakan keterampilan yang didapatkan dengan cara dilatih dan dipelajari secara sungguh-sungguh. Keterampilan menulis tidak bisa didapatkan secara alamiah saja. Faktor utama supaya memiliki keterampilan menulis yang baik yaitu dengan selalu berlatih menuliskan gagasan dan pemikiran dalam wujud tulisan dengan penuh ketelitian, mempersiapkan pengetahuan yang luas, dan pola pikir yang logis (Noermanzah, dkk., 2018:116). Latihan menulis menjadi kunci utama dalam mendapatkan kemampuan menulis yang baik dan benar.

Keterampilan menulis merupakan keterampilan yang harus dimiliki oleh setiap mahasiswa. Dengan keterampilan menulis yang dikuasai, mahasiswa akan mampu mengutarakan ide dan gagasan dengan menggunakan bahasa secara tertulis. Dalam hal ini, keterampilan menulis menjadi hal yang penting bagi mahasiswa dalam pengembangan akademiknya (Derish, dkk., 2007:177-178). Keterampilan menulis juga merupakan sarana komunikasi. Komunikasi dalam kegiatan menulis memiliki empat unsur pokok. Pertama, menulis merupakan suatu wujud ekspresi diri. Kedua, menulis merupakan sesuatu hal yang disampaikan pada pembaca. Ketiga, menulis merupakan suatu aturan dan tingkah laku. Keempat, menulis merupakan suatu cara untuk belajar (Wiyanto, 2008:2).

Kemampuan menulis artikel ilmiah harus dikuasai oleh setiap mahasiswa. Kemampuan menulis artikel ilmiah tersebut bisa diterapkan dalam mengerjakan berbagai tugas akademis dari setiap mata kuliah. Selain itu, kemampuan menulis artikel ilmiah juga menjadi langkah awal sebagai latihan untuk menyusun tugas akhir skripsi. Bahkan saat ini, setiap mahasiswa harus menulis artikel ilmiah dari tugas akhir skripsi/tesis/disertasi yang disusun untuk dimuat di jurnal ilmiah. Oleh karena itu, mahasiswa harus menguasai kemampuan menulis artikel ilmiah sesuai dengan kaidah penulisan karya ilmiah yang tepat.

Berdasarkan hasil refleksi awal yang telah dilakukan, diperoleh hasil bahwa mahasiswa semester II Program Studi (Prodi) Sistem Komputer Universitas Islam Balitar (Unisba) Blitar, masih banyak yang mengalami kesulitan dalam menulis artikel ilmiah. Mahasiswa masih banyak yang mendapatkan nilai rendah dalam 
menulis artikel ilmiah. Dari rentangan nilai yang digunakan mulai dari kategori sangat baik (A), baik (B), cukup (C), kurang (D), dan sangat kurang (E), sebagian besar mahasiswa memperoleh nilai kurang (D) dan sangat kurang (E).

Kesulitan yang dialami oleh mahasiswa tersebut meliputi kesulitan dalam menuliskan bagian judul, pendahuluan, pembahasan, penutup, dan daftar pustaka/referensi. Pada bagian judul, mahasiswa masih kesulitan dalam menentukan aspek kemenarikan, kesesuaian dengan pokok/isi yang dibahas, dan ejaan bahasa Indonesia. Pada bagian pedahuluan, mahasiswa masih kesulitan dalam menentukan aspek kesesuaian pendahuluan dengan pokok/isi yang dibahas, kelengkapan, keruntutan, keefektifan kalimat, penulisan ejaan, penggunaan tanda baca, dan kepaduan paragraf. Pada bagian pembahasan, mahasiswa masih kesulitan dalam menentukan aspek kesesuaian pembahasan dengan pokok/isi yang dibahas, kelengkapan, keruntutan, keefektifan kalimat, penulisan ejaan, penggunaan tanda baca, dan kepaduan paragraf. Pada bagian penutup, mahasiswa masih kesulitan dalam menentukan aspek kesesuaian penutup dengan pokok/isi yang dibahas, keefektifan kalimat, kepaduan paragraf, penulisan ejaan, dan penggunaan tanda baca. Pada bagian penulisan daftar pustaka, mahasiswa masih kesulitan dalam menuliskan sumber tulisan sesuai dengan kaidah yang benar.

Munculnya persoalan yang dialami mahasiswa tersebut karena berbagai sebab. Berdasakan hasil observasi dan wawancara yang peneliti lakukan pada tahap awal, diketahui bahwa terdapat berbagai faktor yang menyebabkan masih rendahnya kemampuan mahasiswa dalam menulis artikel ilmiah. Penyebab pertama, berkaitan dengan faktor internal dari mahasiswa. Faktor internal tersebut meliputi penguasaan bahasa Indonesia yang masih kurang, motivasi belajar yang rendah, dan ketahanan belajar yang rendah. Penyebab kedua, berkaitan dengan faktor eksternal. Faktor eksternal tersebut meliputi materi pembelajaran dan strategi pembelajaran yang digunakan kurang efektif.

Menurut Blumner (2008:21), biasanya teknik menulis dan aspek kebahasaan menjadi kekurangan suatu tulisan. Bagi penulis pemula, persoalan dalam kebahasaan yang muncul seperti kesesuaian, kemenarikan, keruntutan, 
keefektifan kalimat, kepaduan paragraf, penulisan ejaan, penggunaan tanda baca, dan pilihan kata. Masalah selanjutnya yang sering muncul yaitu penyajian yang tidak konsisten.

Permasalahan dalam menulis memiliki hubungan dengan proses pembelajaran bahasa. Pembelajaran bahasa yang dilakukan perlu memperhatikan sudut pandang pembelajaran bahasa sebagai suatu sistem dengan peningkatan kemampuan bahasa bersituasi komunikatif. Menurut Rijlaarsdam, dkk. (2008:2), permasalahan dalam menulis muncul sebab adanya perubahan dari cara sudut pandang. Perubahan tersebut yakni perubahan bahasa sebagai alat komunikasi. Dalam mempelajari bahasa dimulai dari bahasa sebagai suatu sistem menjadi peningkatan bahasa dalam situasi komunikatif. Dengan demikian, proses pembelajaran berubah yakni dari proses pembelajaran sebagai suatu pemerolehan pengetahuan menuju pembelajaran sebagai proses partisipasi.

Penelitian yang dilakukan ini berkaitan dengan proses pembelajaran menulis artikel ilmiah. Penelitian ini difokuskan untuk meningkatkan kemampuan mahasiswa menulis artikel ilmiah. Artikel ilmiah dipilih dalam penelitian ini dengan pertimbangan bahwa tugas-tugas mahasiswa yang diberikan oleh dosen mulai dari semester awal hingga akhir banyak berkaitan dengan menulis artikel ilmiah. Selain itu, ketika di semester akhir, mahasiswa yang mengambil Matakuliah Skripsi juga akan menulis artikel ilmiah dari penelitian yang telah dilakukan. Sebagian besar dosen tidak memberikan penjelasan secara rinci tentang sistematika dan tata cara penulisan artikel ilmiah. Kalaupun ada, sistematika artikel ilmiah yang dijelaskan tidak seragam.

Dalam meningkatkan kemampuan mahasiswa menulis artikel ilmiah, seorang dosen dituntut harus mampu menciptakan kegiatan belajar yang berkualitas. Salah satu aspek penentu kegiatan pembelajaran yang berkualitas yaitu ketepatan dalam menentukan strategi pembelajaran. Strategi pembelajaran yang diyakini tepat untuk meningkatkan kemampuan mahasiswa dalam menulis artikel ilmiah yaitu strategi pembelajaran berbasis kecerdasan verbal linguistik.

Strategi pembelajaran berbasis kecerdasan verbal linguistik bertujuan untuk meningkatkan, memperbaiki, dan mengubah keadaan perkuliahan menulis artikel 
ilmiah dengan menitikberatkan pada aspek kemampuan verbal linguistik setiap mahasiswa. Kemampuan verbal linguistik tersebut meliputi kemampuan dalam hal struktur bahasa, fonologi, semantik, dan pragmatis dari bahasa. Kegiatan pembelajaran yang dilakukan lebih difokuskan pada aspek peningkatan kecerdasan linguistik, mulai dari membaca, mendengarkan, berargumentasi, hingga pratik menulis.

Kecerdasan verbal linguistik (linguistic intelligence) merupakan salah satu bagian kecerdasan yang terdapat dalam kecerdasan jamak atau multiple intelligences sesuai dengan yang diuraikan oleh Howard Gardner. Kecerdasan verbal linguistik merupakan kecerdasan seseorang dalam menggunakan katakata secara efektif, baik dilakukan secara lisan maupun tulisan. Kemampuan yang dimiliki oleh seseorang berkaitan dengan kecerdasan verbal linguistik, yaitu kemampuan dalam memanipulasi struktur bahasa, makna bahasa, bunyi bahasa, dan kegunaan praktis dari bahasa (Amstrong, 2013:6).

Saat ini, artikel ilmiah banyak yang dipublikasikan dalam jurnal ilmiah baik secara cetak maupun online. Menurut Romli (2011:2), artikel ilmiah merupakan suatu tulisan yang berisi tentang hasil kajian dan argumentasi ilmiah yang berkaitan dengan ilmu pengetahuan. Secara umum, struktur artikel ilmiah terdiri atas judul (head), nama penulis (by line), pendahuluan-lead (intro), bridging (penghubung antara intro dengan isi dalam bentuk identifikasi masalah atau pertanyaan), body (isi tulisan yang umumnya terdiri dari sub-sub judul), dan closing (penutup, umumnya berisi simpulan, ajakan, atau pertanyaan tanpa jawaban) (Romli, 2011:4).

Artikel ilmiah merupakan salah satu jenis dari karya ilmiah. Dengan demikian, ciri-ciri pokok dalam karya ilmiah harus ada di dalam artikel ilmiah. Wardani (2006:1.7) menjelaskan ciri-ciri karya ilmiah sebagai berikut. Pertama, pada bagian isi, karya ilmiah menyajikan pengetahuan baik dalam bentuk gagasan, deskripsi, maupun pemecahan masalah tertentu. Kedua, pengetahuan yang disajikan didasarkan pada fakta, data, atau teori-teori yang kebenarannya sudah tidak diragukan. Ketiga, karya ilmiah mengandung kebenaran yang objektif dan kejujuran dalam penulisannya. Keempat, bahasa yang digunakan dalam 
karya ilmiah merupakan ragam bahasa baku. Kelima, sistematika penulisan karya ilmiah mengikuti cara tertentu.

Langkah-langkah menulis artikel ilmiah sebagai berikut. Pertama, pemilihan tema/topik berkaitan dengan artikel ilmiah yang akan ditulis. Kedua, pengembangan tema/topik, bisa melalui studi pustaka/referensi, hasil observasi, dan hasil penelitian. Ketiga, menyusun outlining, yaitu menyusun kerangka artikel ilmiah. Keempat, mengembangkan kerangka artikel ilmiah menjadi draf artikel ilmiah. Kelima, menyunting draf artikel ilmiah.

Penelitian tentang peningkatan kemampuan menulis artikel ilmiah melalui strategi pembelajaran berbasis kecerdasan verbal linguistik belum pernah dilakukan. Penelitian yang banyak dilakukan yaitu berkaitan dengan peningkatan kemampaun menulis karya ilmiah. Penelitian yang sudah dilakukan sebelumnya dan relevan dengan penelitian ini sebagai berikut. Pertama, penelitian yang dilakukan oleh Zulkarnaini (2014) yang berjudul "Peningkatan Kemampuan Menulis Karya IImiah Mahasiswa PGSD Semester I melalui Drill Methode". Hasil dari penelitian tersebut yaitu penggunaan Drill Methode dalam kegiatan pembelajaran bisa meningkatkan keterampilan mahasiswa dalam menulis karya ilmiah. Kedua, penelitian yang dilakukan oleh Halidjah (2015) yang berjudul "Peningkatan Keterampilan Menulis Karya IImiah melalui Lesson Study". Hasil dari penelitian tersebut yaitu penggunaan Lesson Study dalam kegiatan pembelajaran dapat meningkatkan keterampilan mahasiswa dalam menulis karya ilmiah. Ketiga, penelitian yang dilakukan oleh Marselina (2018) yang berjudul "Peningkatan Keterampilan Menulis Karya IImiah melalui Strategi Belajar Kooperatif Tipe Group Investigation Siswa Kelas XI MAN I Kota Sungai Penuh". Hasil dari penelitian tersebut yaitu penggunaan strategi pembelajaran kooperatif tipe Group Investigation bisa meningkatkan keterampilan siswa kelas XI MAN I Kota Sungai Penuh dalam menulis karya ilmiah.

Ketiga penelitian yang telah dilakukan tersebut memiliki persamaan dan perbedaan dengan penelitian ini. Persamaan antara ketiga penelitian tersebut dengan penelitian ini adalah sama-sama penelitian tindakan kelas untuk meningkatkan kemampuan menulis karya ilmiah. Perbedaan antara ketiga penelitian tersebut dengan penelitian ini terletak pada jenis karya ilmiahnya. 
Ketiga penelitian tersebut bertujuan untuk meningkatkan kemampuan siswa dalam menulis makalah, sedangkan penelitian ini bertujuan untuk meningkatkan kemampuan mahasiswa dalam menulis artikel ilmiah. Perbedaan selanjutnya berkaitan dengan strategi pembelajaran yang digunakan dalam penelitian. Penelitian yang dilakukan oleh Zulkarnaini menggunakan Drill Methode, Halidjah menggunakan Lesson Study, dan Marselina menggunakan strategi pembelajaran kooperatif tipe group investigation, sedangkan dalam penelitian ini strategi pembelajaran yang digunakan berbasis kecerdasan verbal linguistik.

Berdasarkan berbagai permasalahan yang sudah diuraikan tersebut, perlu adanya upaya untuk meningkatkan kemampuan mahasiswa dalam menulis artikel ilmiah. Upaya yang dapat dilakukan yaitu dengan memperbaiki proses pembelajaran menulis artikel ilmiah menggunakan strategi pembelajaran berbasis kecerdasan verbal linguistik. Kegiatan yang dilakukan tersebut dalam bentuk penelitian tindakan kelas (PTK). Judul dalam penelitian ini yaitu "Peningkatan Kemampuan Menulis Artikel Ilmiah melalui Strategi Pembelajaran Berbasis Kecerdasan Verbal Linguistik". Tujuan dari penelitian ini adalah meningkatkan kemampuan mahasiswa semester II Prodi Sistem Komputer Unisba Blitar dalam menulis artikel ilmiah dengan menggunakan strategi pembelajaran berbasis kecerdasan verbal linguistik.

\section{B. Metode Penelitian}

Penelitian ini dilakukan dengan menggunakan pendekatan kualitatif. Seluruh fakta yang ada di lapangan, baik secara lisan maupun tulisan akan dicatat dan dideskripsikan untuk dikaji. Proses pengkajian terhadap data-data tersebut untuk memperoleh makna dari temuan penelitian. Penelitian yang dilakukan ini merupakan penelitian tindakan kelas (classroom action research). Tujuan dari penelitian ini adalah untuk meningkatkan kemampuan mahasiswa dalam menulis artikel ilmiah. Data yang digunakan dalam penelitian ini berupa data proses pembelajaran dan data produk hasil pembelajaran.

Sumber data penelitian ini adalah seluruh mahasiswa semester II kelas A Prodi Sistem Komputer Unisba Blitar. Mahasiswa di kelas A tersebut berjumlah 6 
mahasiswa yang semuanya laki-laki. Instrumen yang digunakan dalam penelitian ini adalah peneliti sendiri. Hal ini karena dalam proses kegiatan pengumpulan data, peneliti melaksanakan adaptasi secara langsung sesuai dengan kondisi yang ada di lapangan. Peneliti juga menggunakan instrumen lain yaitu pedoman wawancara, pedoman analisis dokumen, dan pedoman observasi. Instrumeninstrumen tersebut digunakan sebagai upaya untuk menjaga fokus masalah dalam penelitian.

Penelitian ini menggunakan prosedur kerja dengan mengadaptasi prosedur kerja dari Kemmis \& Mc.Taggart (1988), yaitu dengan prosedur kerja penelitian ini dimulai dari perencanaan tindakan, pelaksanaan tindakan, observasi, dan refleksi. Sebelum melaksanakan berbagai kegiatan tersebut, dilakukan studi pendahuluan untuk menentukan permasalahan yang perlu ditindaklanjuti. Penelitian ini dilaksanakan dalam dua siklus, yaitu siklus I dan siklus II.

\section{Hasil Penelitian dan Pembahasan}

\section{Hasil Penelitian}

Pada bagian hasil penelitian berisi uraian yang berkaitan dengan kegiatan studi pendahuluan, siklus I, dan siklus II. Kegiatan studi pendahuluan dilaksanakan untuk mengetahui kemampuan awal mahasiswa dalam menulis artikel ilmiah. Kegiatan siklus I merupakan tindakan khusus yang dilakukan untuk mengatasi persoalan yang dialami oleh mahasiswa dalam menulis artikel ilmiah. Kegiatan siklus II merupakan tindakan lanjutan yang dilakukan untuk mengatasi persoalan yang dialami oleh mahasiswa dalam menulis artikel ilmiah yang belum teratasi secara menyeluruh pada kegiatan siklus I. Secara rinci, hasil dari penelitian ini diuraikan sebagai berikut.

Pertama, uraian tentang kegiatan studi pendahuluan. Kegiatan studi pendahuluan dilakukan sebanyak dua kali pertemuan. Pertemuan pertama dilakukan pada hari Selasa, 2 April 2019 mulai pukul 09.00 - 10.40 WIB. Kegiatan pada pertemuan pertama ini dilakukan di ruang A2.09. Pertemuan kedua dilakukan pada hari Selasa, 9 April 2019 mulai pukul 09.00 - 10.40 WIB. Kegiatan pada pertemuan kedua ini dilakukan di ruang A2.09. 
Pada kegiatan studi pendahuluan, kegiatan perkuliahan pada pertemuan pertama yaitu penyampaian materi perkuliahan berkaitan dengan materi menulis artikel ilmiah. Secara umum, kegiatan perkuliahan yang dilaksanakan sebagai berikut. Pada kegiatan awal perkuliahan, dosen menyampaikan tujuan dari pembelajaran. Selanjutnya, dosen menjelaskan materi tentang menulis artikel ilmiah. Kemudian, mahasiswa dipersilahkan untuk bertanya berkaitan dengan materi yang belum dipahami. Selanjutnya, mahasiswa diberikan tugas untuk menulis artikel ilmiah. Tugas tersebut harus dikerjakan oleh mahasiswa dalam waktu tidak lebih dari 2 × 50 menit. Mahasiswa diberikan waktu tambahan untuk mengerjakan tugas tersebut di luar jam perkuliahan. Tugas dari mahasiswa tersebut akan dibahas pada pertemuan berikutnya. Pertemuan kedua, mahasiswa saling menukarkan tugas menulis artikel ilmiah yang sudah dikerjakan dengan mahasiswa yang lain. Setelah tugas menulis artikel ilmiah tersebut ditukarkan, tugas masing-masing mahasiswa adalah mengomentari dan mengoreksi tugas dari temannya sesuai dengan pedoman penilaian yang diberikan oleh dosen. Setelah itu, tugas tersebut dikumpulkan kepada dosen.

Berdasarkan kegiatan pembelajaran pada studi pendahuluan, diperoleh hasil sebagai berikut. Pertama, berkaitan dengan proses pembelajaran, mahasiswa tampak kurang begitu aktif dalam mengikuti perkuliahan. Kedua, berkaitan dengan produk hasil pembelajaran, hasil artikel ilmiah yang ditulis mahasiswa masih banyak yang mendapatkan nilai di bawah KKM. Kelulusan hasil belajar mahasiswa ditentukan sesuai dengan standar KKM yaitu $\geq 60$. Hasil penilaian terhadap tugas mahasiswa tersebut disajikan pada tabel 1 berikut.

Tabel 1. Hasil Penilaian pada Studi Pendahuluan

\begin{tabular}{lccccccc}
\hline No. & Range & Nilai & Judul & Pendahuluan & $\begin{array}{c}\text { Aspek Penilaian } \\
\text { Pembahasan }\end{array}$ & Penutup & Referensi \\
\hline 1. & $\geq 85$ & A & 0 & 0 & 0 & 0 & 0 \\
\hline 2. & $75-84$ & B & 1 & 1 & 1 & 1 & 1 \\
\hline 3. & $60-74$ & C & 2 & 1 & 1 & 2 & 1 \\
\hline 4. & $50-59$ & D & 3 & 3 & 2 & 3 & 3 \\
\hline 5. & $<50$ & E & 0 & 1 & 2 & 0 & 1 \\
\hline
\end{tabular}

Data pada tabel 1 tersebut, dapat dijelaskan sebagai berikut. Pertama, berkaitan dengan kemampuan mahasiswa dalam menulis judul artikel ilmiah 
masih banyak yang mendapatkan nilai di bawah KKM. Hasil penilaian dari tugas mahasiswa pada bagian penulisan judul sebagai berikut. Mahasiswa yang mendapatkan nilai $A(\geq 85)$ tidak ada, nilai $B(75-84)$ sebanyak 1 mahasiswa, nilai C (60 - 74) sebanyak 2 mahasiswa, nilai D (50 - 59) sebanyak 3 mahasiswa, dan nilai $E(<50)$ tidak ada. Dengan demikian, mahasiswa yang mendapatkan nilai di bawah KKM sebanyak 3 mahasiswa.

Kedua, berkaitan dengan kemampuan mahasiswa menulis bagian pendahuluan pada artikel ilmiah masih banyak yang mendapatkan nilai di bawah KKM. Hasil penilaian dari tugas mahasiswa pada bagian pendahuluan sebagai berikut. Mahasiswa yang mendapatkan nilai $A(\geq 85)$ tidak ada, nilai B (75 - 84) sebanyak 1 mahasiswa, nilai C (60 - 74) sebanyak 1 mahasiswa, dan nilai D (50 59) sebanyak 3 mahasiswa, dan nilai E (<50) sebanyak 1 mahasiswa. Dengan demikian, mahasiswa yang mendapatkan nilai di bawah KKM sebanyak 4 mahasiswa.

Ketiga, berkaitan dengan kemampuan mahasiswa menulis bagian pembahasan pada artikel ilmiah masih banyak yang mendapatkan nilai di bawah KKM. Hasil penilaian dari tugas mahasiswa pada bagian pembahasan sebagai berikut. Mahasiswa yang mendapatkan nilai A ( $\geq 85)$ tidak ada, nilai B (75 - 84) sebanyak 1 mahasiswa, nilai C (60 - 74) sebanyak 1 mahasiswa, nilai D (50 - 59) sebanyak 2 mahasiswa, dan nilai $E(<50)$ sebanyak 2 mahasiswa. Dengan demikian, mahasiswa yang mendapatkan nilai di bawah KKM sebanyak 4 mahasiswa.

Keempat, berkaitan dengan kemampuan mahasiswa menulis bagian penutup pada artikel ilmiah masih banyak yang mendapatkan nilai di bawah KKM. Hasil penilaian dari tugas mahasiswa pada bagian penutup sebagai berikut. Mahasiswa yang mendapatkan nilai A ( $\geq 85)$ tidak ada, nilai B (75 - 84) sebanyak 1 mahasiswa, nilai $C(60-74)$ sebanyak 2 mahasiswa, nilai $D(50-59)$ sebanyak 3 mahasiswa, dan nilai $\mathrm{E}(<50)$ tidak ada. Dengan demikian, mahasiswa yang mendapatkan nilai di bawah KKM sebanyak 3 mahasiswa.

Kelima, berkaitan dengan kemampuan mahasiswa menulis bagian referensi pada artikel ilmiah masih banyak yang mendapatkan nilai di bawah KKM. Hasil penilaian dari tugas mahasiswa pada bagian penulisan referensi sebagai berikut. 
Mahasiswa yang mendapatkan nilai A ( $\geq 85)$ tidak ada, nilai B (75 - 84) sebanyak 1 mahasiswa, nilai C (60 - 74) sebanyak 1 mahasiswa, nilai D (50 - 59) sebanyak 3 mahasiswa, dan nilai $E(<50)$ sebanyak 1 mahasiswa. Dengan demikian, mahasiswa yang mendapatkan nilai di bawah KKM sebanyak 4 mahasiswa.

Berdasarkan hasil dari studi pendahuluan yang telah dilakukan tersebut diketahui bahwa mahasiswa masih banyak yang belum tuntas/lulus dalam materi menulis artikel ilmiah. Hal ini dapat dilihat dari masih banyaknya mahasiswa yang mendapatkan nilai di bawah standar KKM yang telah ditetapkan. Oleh karena itu, dosen dan observer menyepakati dilaksanakannya tindakan khusus untuk meningkatkan kemampuan mahasiswa dalam menulis artikel ilmiah. Tindakan tersebut dilakukan dalam beberapa siklus sampai tujuan untuk meningkatkan kemampuan mahasiswa dalam menulis artikel ilmiah tercapai. Tindakan yang dilakukan difokuskan pada proses pembelajaran dan produk hasil pembelajaran. Pada proses pembelajaran, tindakan yang dilakukan untuk meningkatkan keaktifan dan keantusiasan mahasiswa dalam mengikuti pembelajaran. Pada produk hasil pembelajaran, tindakan yang dilakukan difokuskan pada aspek penulisan judul, pendahuluan, pembahasan, penutup, serta daftar pustaka/referensi dengan menggunakan strategi pembelajaran berbasis kecerdasan verbal linguistik.

Pelaksanaan tindakan pada siklus I dilakukan setelah kegiatan studi pendahuluan dianalisis dan direfleksi. Tindakan pada siklus I dilaksanakan dalam dua pertemuan pembelajaran. Setiap pertemuan pembelajaran dilakukan selama $2 \times 50$ menit atau dua jam pelajaran. Pertemuan pertama dilaksanakan pada hari Selasa, 16 April 2019 mulai pukul 09.00 - 10.40 WIB. Pertemuan kedua dilaksanakan pada hari Senin, 22 April 2019 mulai pukul 09.00 - 10.40 WIB. Kegiatan pembelajaran pada siklus I dilaksanakan di ruang A2.09.

Kegiatan belajar pada siklus I ini dilaksanakan dengan menggunakan strategi pembelajaran berbasis kecerdasan verbal linguistik. Langkah-langkah pembelajaran tersebut sebagai berikut. Pertama, kegiatan apersepsi tentang materi artikel ilmiah. Materi yang digali pada tahap ini berkaitan dengan pengertian artikel ilmiah, macam-macam artikel ilmiah, dan sistematika penulisan artikel 
ilmiah. Kedua, kegiatan brainstorming berkaitan dengan materi menulis artikel ilmiah, seperti unsur-unsur yang perlu diperhatikan dalam menulis artikel ilmiah, mulai dari penggunaan ejaan dan tanda baca, penggunaan diksi, penulisan kalimat efektif, dan kepaduan dalam menyusun paragraf. Ketiga, penjelasan tentang kompetensi dasar dan tujuan pembelajaran. Keempat, penjelasan tentang strategi pembelajaran berbasis kecerdasan linguistik. Kelima, penjelasan tentang materi menulis artikel ilmiah. Keenam, pembagian lembar kerja mahasiswa untuk kegiatan latihan. Ketujuh, menentukan topik dan judul yang menarik untuk dikembangkan menjadi artikel ilmiah. Kedelapan, menulis kerangka artikel ilmiah sesuai dengan judul yang telah ditentukan. Kesembilan, mengembangkan pokokpokok masalah sesuai dengan kerangka artikel ilmiah yang telah dibuat ke dalam bentuk artikel ilmiah dengan memperhatikan sistematika penulisan artikel ilmiah, penggunaan ejaan dan tanda baca, penggunaan diksi, penulisan kalimat efektif, dan penulisan paragraf yang tepat. Kegiatan ini dilaksanakan di kelas dan dilanjutkan di rumah dalam bentuk diketik. Kesepuluh, mahasiswa menunjukkan artikel ilmiah yang telah ditulis kepada dosen. Artikel ilmiah tersebut selanjutnya ditukarkan dengan mahasiswa lain untuk dikomentari dan dinilai. Penilaian yang dilakukan mahasiswa sesuai dengan pedoman penilaian yang diberikan oleh dosen. Penilaian tersebut meliputi sistematika penulisan artikel ilmiah (judul, pendahuluan, pembahasan, penutup, referensi/daftar pustaka) penggunaan ejaan dan tanda baca, penggunaan diksi, penulisan kalimat efektif, dan kepaduan dalam menyusun paragraf. Kesebelas, beberapa mahasiswa menjelaskan hasil penilaian artikel ilmiah yang ditulis temannya di depan dan mahasiswa yang lain memberikan komentar. Keduabelas, mahasiswa melakukan refleksi terhadap kesulitan yang dialami selama proses pembelajaran. Ketigabelas, dosen memberikan penguatan terhadap pembelajaran yang telah dilakukan.

Berdasarkan kegiatan belajar pada siklus I, diperoleh hasil sebagai berikut. Pertama, berkaitan dengan proses pembelajaran, mahasiswa tampak begitu aktif dalam mengikuti perkuliahan. Kedua, berkaitan dengan produk hasil pembelajaran, hasil artikel ilmiah yang ditulis mahasiswa sudah mendapatkan nilai KKM. Namun, masih ada mahasiswa yang mendapatkan nilai di bawah KKM. 
Hasil penilaian terhadap tugas mahasiswa tersebut disajikan pada tabel 2 sebagai berikut.

Tabel 2. Hasil Penilaian pada Siklus I

\begin{tabular}{lccccccc}
\hline No. & Range & Nilai & \multicolumn{5}{c}{ Aspek Penilaian } \\
\cline { 4 - 8 } & & & Judul & Pendahuluan & Pembahasan & Penutup & Referensi \\
\hline 1. & $\geq 85$ & A & 2 & 1 & 2 & 2 & 2 \\
\hline 2. & $75-84$ & B & 2 & 2 & 1 & 2 & 2 \\
\hline 3. & $60-74$ & C & 2 & 1 & 1 & 1 & 1 \\
\hline 4. & $50-59$ & D & 0 & 2 & 1 & 1 & 1 \\
\hline 5. & $<50$ & E & 0 & 0 & 1 & 0 & 0 \\
\hline
\end{tabular}

Data pada tabel 2 tersebut dapat dijelaskan sebagai berikut. Pertama, berkaitan dengan kemampuan menulis judul artikel ilmiah, semua mahasiswa sudah mencapai standar KKM. Hasil penilaian dari tugas mahasiswa pada bagian penulisan judul sebagai berikut. Mahasiswa yang mendapatkan nilai A $(\geq 85)$ sebanyak 2 mahasiswa, nilai B $(75$ - 84) sebanyak 2 mahasiswa, nilai C $(60-74)$ sebanyak 2 mahasiswa, nilai D (50 - 59) tidak ada, dan nilai $E(<50)$ tidak ada. Dengan demikian, mahasiswa yang mendapatkan nilai di bawah KKM dan dinyatakan belum lulus pada bagian penulisan judul tidak ada.

Kedua, berkaitan dengan kemampuan menulis bagian pendahuluan pada artikel ilmiah, sebagian besar mahasiswa sudah mencapai standar KKM. Hasil penilaian dari tugas mahasiswa pada bagian pendahuluan sebagai berikut. Mahasiswa yang mendapatkan nilai $A(\geq 85)$ sebanyak 1 mahasiswa, nilai $B(75$ 84) sebanyak 2 mahasiswa, nilai C (60 - 74) sebanyak 1 mahasiswa, nilai D (50 59) sebanyak 2 mahasiswa, dan nilai $E(<50)$ tidak ada. Dengan demikian, mahasiswa yang mendapatkan nilai di bawah KKM dan dinyatakan belum lulus sebanyak 2 mahasiswa.

Ketiga, berkaitan dengan kemampuan menulis bagian pembahasan pada artikel ilmiah, sebagian besar mahasiswa sudah mencapai standar KKM. Hasil penilaian dari tugas mahasiswa pada bagian pembahasan sebagai berikut. Mahasiswa yang mendapatkan nilai $A(\geq 85)$ sebanyak 2 mahasiswa, nilai B (75 84) sebanyak 1 mahasiswa, nilai $C(60-74)$ sebanyak 1 mahasiswa, nilai D (50 59) sebanyak 1 mahasiswa, dan nilai $E(<50)$ sebanyak 1 mahasiswa. Dengan 
demikian, mahasiswa yang mendapatkan nilai di bawah KKM dan dinyatakan belum lulus sebanyak 2 mahasiswa.

Keempat, berkaitan dengan kemampuan menulis bagian penutup pada artikel ilmiah, sebagian besar mahasiswa sudah mencapai standar KKM. Hasil penilaian dari tugas mahasiswa pada bagian penutup sebagai berikut. Mahasiswa yang mendapatkan nilai A ( $\geq 85)$ sebanyak 2 mahasiswa, nilai B (75 - 84) sebanyak 2 mahasiswa, nilai $C(60-74)$ sebanyak 1 mahasiswa, nilai D (50 - 59) sebanyak 1 mahasiswa, dan nilai $\mathrm{E}(<50)$ tidak ada. Dengan demikian, mahasiswa yang mendapatkan nilai di bawah KKM dan dinyatakan belum lulus sebanyak 1 mahasiswa.

Kelima, berkaitan dengan kemampuan menulis bagian referensi pada artikel ilmiah, sebagian besar mahasiswa sudah mencapai standar KKM. Hasil penilaian dari tugas mahasiswa pada bagian penulisan referensi sebagai berikut. Mahasiswa yang mendapatkan nilai $A(\geq 85)$ sebanyak 2 mahasiswa, nilai B (75 84) sebanyak 2 mahasiswa, nilai C (60 - 74) sebanyak 1 mahasiswa, nilai D (0 59) sebanyak 1 mahasiswa, dan nilai $E(<50)$ tidak ada. Dengan demikian, mahasiswa yang mendapatkan nilai di bawah KKM dan dinyatakan belum lulus sebanyak 1 mahasiswa.

Berdasarkan hasil dari kegiatan belajar pada siklus I tersebut dapat dinyatakan belum berhasil meningkatkan kemampuan seluruh mahasiswa dalam menulis artikel ilmiah. Hal ini karena masih ada mahasiswa yang mendapatkan nilai di bawah KKM dan dinyatakan belum lulus. Oleh karena itu, dosen dan observer sepakat untuk dilakukan tindakan siklus II. Tindakan yang dilakukan pada siklus II ini bertujuan untuk memperbaiki berbagai kekurangan yang terjadi selama proses pembelajaran pada siklus I.

Pelaksanaan tindakan pada siklus II dilakukan dalam dua kali pertemuan pembelajaran. Setiap satu kali pertemuan pembelajaran dilakukan selama $2 \times 50$ menit atau dua jam pelajaran. Pertemuan pertama dilaksanakan pada hari Selasa, 30 April 2019 mulai pukul 09.00 - 10.40 WIB. Pertemuan kedua dilaksanakan pada hari Jumat, 3 Mei 2019 mulai pukul 09.00 - 10.40 WIB. Kegiatan pembelajaran pada siklus II dilaksanakan di ruang A2.09. Kegiatan belajar pada siklus II ini dilaksanakan dengan menggunakan strategi pembelajaran berbasis 
kecerdasan verbal linguistik. Perbedaan proses pembelajaran dengan siklus I terletak pada jumlah media pembelajaran yang digunakan.

Berdasarkan kegiatan belajar pada siklus II, diperoleh hasil sebagai berikut Pertama, berkaitan dengan proses pembelajaran, mahasiswa tampak begitu aktif dan antusias dalam mengikuti perkuliahan. Kedua, berkaitan dengan produk hasil pembelajaran, hasil artikel ilmiah yang ditulis mahasiswa, seluruhnya sudah mendapatkan nilai KKM. Hasil penilaian terhadap tugas mahasiswa tersebut disajikan pada tabel 3 sebagai berikut.

Tabel 3. Hasil Penilaian pada Siklus II

\begin{tabular}{lccccccc}
\hline No. & Range & Nilai & \multicolumn{5}{c}{ Aspek Penilaian } \\
\cline { 4 - 8 } & & & Judul & Pendahuluan & Pembahasan & Penutup & Referensi \\
\hline 1. & $\geq 85$ & A & 3 & 2 & 2 & 3 & 3 \\
\hline 2. & $75-84$ & B & 2 & 3 & 3 & 2 & 2 \\
\hline 3. & $60-74$ & C & 1 & 1 & 1 & 1 & 1 \\
\hline 4. & $50-59$ & D & 0 & 0 & 0 & 0 & 0 \\
\hline 5. & $<50$ & E & 0 & 0 & 0 & 0 & 0 \\
\hline
\end{tabular}

Data pada tabel 3 tersebut dapat dijelaskan sebagai berikut. Pertama, berkaitan dengan kemampuan menulis judul artikel ilmiah, mahasiswa sudah mencapai standar KKM. Hasil penilaian dari tugas mahasiswa pada bagian penulisan judul sebagai berikut. Mahasiswa yang mendapatkan nilai A $(\geq 85)$ sebanyak 3 mahasiswa, nilai B (75 - 84) sebanyak 2 mahasiswa, nilai C (60 - 74) sebanyak 1 mahasiswa, nilai D $(50-59)$ dan $E(<50)$ tidak ada. Dengan demikian, mahasiswa dinyatakan lulus semua dalam menulis bagian judul pada artikel ilmiah.

Kedua, berkaitan dengan kemampuan menulis bagian pendahuluan pada artikel ilmiah, mahasiswa sudah mencapai standar KKM. Hasil penilaian dari tugas mahasiswa pada bagian pendahuluan sebagai berikut. Mahasiswa yang mendapatkan nilai $A(\geq 85)$ sebanyak 2 mahasiswa, nilai $B(75-84)$ sebanyak 3 mahasiswa, nilai C (60 - 74) sebanyak 1 mahasiswa, nilai D (50 - 59) dan $E(<$ 50) tidak ada. Dengan demikian, mahasiswa dinyatakan lulus semua dalam menulis bagian pendahuluan pada artikel ilmiah.

Ketiga, berkaitan dengan kemampuan menulis bagian pembahasan pada artikel ilmiah, mahasiswa sudah mencapai standar KKM. Hasil penilaian dari tugas mahasiswa pada bagian pembahasan sebagai berikut. Mahasiswa yang 
mendapatkan nilai $A(\geq 85)$ sebanyak 2 mahasiswa, nilai $B(75-84)$ sebanyak 3 mahasiswa, nilai C (60 - 74) sebanyak 1 mahasiswa, nilai D (50 - 59) dan E (< 50) tidak ada. Dengan demikian, mahasiswa dinyatakan lulus semua dalam menulis bagian pembahasan pada artikel ilmiah.

Keempat, berkaitan dengan kemampuan menulis bagian penutup pada artikel ilmiah, mahasiswa sudah mencapai standar KKM. Hasil penilaian dari tugas mahasiswa pada bagian penutup sebagai berikut. Mahasiswa yang mendapatkan nilai $A(\geq 85)$ sebanyak 3 mahasiswa, nilai $B(75-84)$ sebanyak 2 mahasiswa, nilai C $(60$ - 74) sebanyak 1 mahasiswa, nilai $D(50$ - 59) dan $E(<50)$ tidak ada. Dengan demikian, mahasiswa dinyatakan lulus semua dalam menulis bagian penutup pada artikel ilmiah.

Kelima, berkaitan dengan kemampuan menulis bagian referensi pada artikel ilmiah, mahasiswa sudah mencapai standar KKM. Hasil penilaian dari tugas mahasiswa pada bagian penulisan referensi/daftar pustaka sebagai berikut. Mahasiswa yang mendapatkan nilai $A(\geq 85)$ sebanyak 3 mahasiswa, nilai B (75 84) sebanyak 2 mahasiswa, nilai C (60 - 74) sebanyak 1 mahasiswa, nilai D (50 59) dan $\mathrm{E}(<50)$ tidak ada. Dengan demikian, mahasiswa dinyatakan lulus semua dalam menulis bagian referensi atau daftar pustaka pada artikel ilmiah.

Berdasarkan hasil penelitian yang sudah dipaparkan tersebut, dapat disimpulkan bahwa kemampuan mahasiswa dalam menulis artikel ilmiah dapat ditingkatkan melalui pembelajaran pada siklus II. Oleh karena itu, dosen dan observer sepakat untuk tidak dilakukan tindakan siklus III karena indikator keberhasilan penelitian sudah tercapai. Indikator penelitian tersebut yaitu terjadinya peningkatan pada proses pembelajaran dan produk hasil pembelajaran. Dari segi proses pembelajaran, telah terjadi peningkatan kualifikasi pembelajaran yang dapat dilihat dari keaktifan dan keantusiasan mahasiswa selama kegiatan pembelajaran berlangsung. Dari segi produk hasil pembelajaran, kemampuan mahasiswa dalam menulis artikel ilmiah dari segi judul, pendahuluan, pembahasan, penutup, dan referensi/daftar pustaka dapat ditingkatkan. 


\section{Pembahasan}

Pada bagian ini akan dibahas tentang peningkatan kemampuan mahasiswa semester II kelas A Prodi Sistem Komputer Unisba Blitar dalam menulis artikel ilmiah dengan menggunakan strategi pembelajaran berbasis kecerdasan verbal linguistik. Peningkatan kemampuan mahasiswa tersebut dapat dilihat dari segi proses maupun produk hasil pembelajaran. Perlu diuraikan pula bahwa dalam penelitian ini terdapat temuan penelitian. Temuan penelitian tersebut dijelaskan sebagai berikut.

Temuan pertama, berkaitan dengan proses pembelajaran. Dari segi proses pembelajaran telah terjadi peningkatan kualifikasi pembelajaran pada materi menulis artikel ilmiah dengan strategi pembelajaran berbasis kecerdasan verbal linguistik. Hal ini tampak dari keaktifan dan keantusiasan mahasiswa selama kegiatan pembelajaran berlangsung.

Temuan kedua, berkaitan dengan produk hasil pembelajaran. Dari segi produk hasil pembelajaran, hasil artikel ilmiah yang ditulis mahasiswa ditinjau dari aspek judul, pendahuluan, pembahasan, penutup, dan daftar pustaka seluruhnya sudah mendapatkan nilai KKM yang artinya sudah lulus. Hal ini menunjukkan bahwa kemampuan mahasiswa dalam menulis artikel ilmiah dapat ditingkatkan dengan strategi pembelajaran berbasis kecerdasan verbal linguistik. Berkaitan dengan temuan produk hasil pembelajaran tersebut, secara rinci dapat diuraikan sebagai berikut.

Pertama, berkaitan dengan kemampuan mahasiswa dalam menulis artikel ilmiah pada bagian judul dapat ditingkatkan dengan menggunakan strategi pembelajaran berbasis kecerdasan verbal linguistik. Hal ini bisa dibuktikan melalui hasil penulisan judul artikel ilmiah yang ditulis mahasiswa. Peningkatan kemampuan mahasiswa dalam menulis bagian judul pada artikel ilmiah yaitu: (1) dari yang sebelumnya tidak menarik menjadi menarik; (2) dari yang sebelumnya tidak sesuai dengan isi/pokok permasalahan yang dibahas menjadi sesuai dengan isi/pokok permasalahan yang dibahas; dan (3) dari yang sebelumnya tidak sesuai dengan penulisan ejaan bahasa Indonesia menjadi sesuai dengan ejaan bahasa Indonesia. 
Kedua, berkaitan dengan kemampuan mahasiswa dalam menulis artikel ilmiah pada bagian pendahuluan dapat ditingkatkan dengan menggunakan strategi pembelajaran berbasis kecerdasan verbal linguistik. Hal ini bisa dibuktikan melalui hasil artikel ilmiah pada bagian pendahuluan yang ditulis mahasiswa. Peningkatan kemampuan mahasiswa dalam menulis bagian pendahuluan pada artikel ilmiah yaitu: (1) dari yang sebelumnya tidak runtut menjadi runtut; (2) dari yang sebelumnya tidak sesuai dengan isi/pokok permasalahan yang dibahas menjadi sesuai dengan pokok permasalahan yang dibahas; (3) dari yang sebelumnya tidak sesuai dengan penulisan ejaan dan tanda baca dalam bahasa Indonesia menjadi sesuai dengan penulisan ejaan dan tanda baca dalam bahasa Indonesia; (4) dari yang sebelumnya tidak efektif dalam penulisan kalimat menjadi efektif dalam penulisan kalimat; dan (5) dari yang sebelumnya tidak padu dalam menuliskan paragraf satu dengan paragraf yang lain menjadi padu.

Ketiga, berkaitan dengan kemampuan mahasiswa dalam menulis artikel ilmiah pada bagian pembahasan dapat ditingkatkan dengan menggunakan strategi pembelajaran berbasis kecerdasan verbal linguistik. Hal ini bisa dibuktikan melalui hasil artikel ilmiah pada bagian pembahasan yang ditulis mahasiswa. Peningkatan kemampuan mahasiswa dalam menulis bagian pembahasan pada artikel ilmiah yaitu: (1) dari yang sebelumnya tidak sesuai dengan isi/pokok permasalahan yang dibahas menjadi sesuai dengan pokok permasalahan yang dibahas; (2) dari yang sebelumnya tidak lengkap menjadi lengkap; (3) dari yang sebelumnya tidak sesuai dengan penulisan ejaan dan tanda baca dalam bahasa Indonesia menjadi sesuai dengan penulisan ejaan dan tanda baca dalam bahasa Indonesia; (4) dari yang sebelumnya tidak efektif dalam penulisan kalimat menjadi efektif dalam penulisan kalimat; dan (5) dari yang sebelumnya tidak padu dalam menuliskan paragraf satu dengan paragraf yang lain menjadi padu.

Keempat, berkaitan dengan kemampuan mahasiswa dalam menulis artikel ilmiah pada bagian penutup dapat ditingkatkan dengan menggunakan strategi pembelajaran berbasis kecerdasan verbal linguistik. Hal ini bisa dibuktikan melalui hasil artikel ilmiah pada bagian penutup yang ditulis mahasiswa. Peningkatan kemampuan mahasiswa dalam menulis bagian penutup pada artikel ilmiah yaitu: (1) dari yang sebelumnya tidak sesuai dengan isi/pokok permasalahan yang 
dibahas menjadi sesuai dengan pokok permasalahan yang dibahas; (2) dari yang sebelumnya tidak sesuai dengan penulisan ejaan dan tanda baca dalam bahasa Indonesia menjadi sesuai dengan penulisan ejaan dan tanda baca dalam bahasa Indonesia; (3) dari yang sebelumnya tidak efektif dalam penulisan kalimat menjadi efektif dalam penulisan kalimat; dan (4) dari yang sebelumnya tidak padu dalam menuliskan paragraf satu dengan paragraf yang lain menjadi padu.

Kelima, berkaitan dengan kemampuan mahasiswa dalam menulis artikel ilmiah pada bagian referensi/daftar pustaka dapat ditingkatkan dengan menggunakan strategi pembelajaran berbasis kecerdasan verbal linguistik. Hal ini bisa dibuktikan melalui hasil artikel ilmiah pada bagian daftar pustaka yang ditulis mahasiswa. Peningkatan kemampuan mahasiswa dalam menulis bagian daftar pustaka pada artikel ilmiah yaitu dari yang sebelumnya tidak sesuai dengan aturan penulisan daftar pustaka menjadi sesuai dengan aturan penulisan daftar pustaka.

Berdasarkan hasil dan temuan penelitian yang telah diuraikan tersebut dapat disimpulkan bahwa kemampuan mahasiswa dalam menulis artikel ilmiah dapat ditingkatkan dengan menggunakan strategi pembelajaran berbasis kecerdasan verbal linguistik. Strategi pembelajaran berbasis kecerdasan verbal linguistik ini pada dasarnya menekankan pada aspek peningkatan kemampuan linguistik mahasiswa sehingga akan mampu meningkatkan kemampuan menulis artikel ilmiah. Langkah-langkah dalam pembelajaran yang dilakukan disusun berdasarkan pola kegiatan yang berbasis kecerdasan verbal linguistik. Dengan kemampuan linguistik yang bagus, mahasiswa akan mampu menggunakan kemampuannya untuk mengungkapkan ide, pikiran, dan gagasan melalui rangkaian kata, kalimat, dan paragraf sehingga tersusunlah suatu artikel ilmiah.

Kegiatan pembelajaran yang dilakukan untuk meningkatkan kemampuan mahasiswa dalam menulis artikel ilmiah pada penelitian ini lebih menitikberatkan pada kegiatan membaca, berargumentasi, tanya jawab, melaporkan informasi, diskusi, dan aktivitas menulis. Hal ini senada dengan pendapat dari Chatib (2012:82) yang menjelaskan bahwa kegiatan pembelajaran berbasis multiple intelligences pada aspek kecerdasan verbal linguistik meliputi: (a) membaca, (b) wawancara, (c) presentasi, (d) mendongeng, (e) bercerita, (f) debat, (g) membuat 
puisi, (h) membuat cerpen, (i) tanya jawab, (j) permainan kosakata, dan (k) melaporkan informasi (reportase).

Kecerdasan verbal linguistik (linguistic intelligence) merupakan salah satu bagian kecerdasan yang terdapat dalam kecerdasan jamak atau multiple intelligences sesuai dengan yang diuraikan oleh Howard Gardner. Kecerdasan verbal linguistik merupakan kecerdasan seseorang dalam menggunakan kata-kata secara efektif, baik dilakukan secara lisan maupun tulisan. Kemampuan yang dimiliki oleh seseorang berkaitan dengan kecerdasan verbal linguistik, yaitu kemampuan dalam memanipulasi struktur bahasa, makna bahasa, bunyi bahasa, dan kegunaan praktis dari bahasa (Amstrong, 2013:6).

Menurut Amstrong (2013: 23), strategi pembelajaran berbasis kecerdasan linguistik bisa diimplementasikan ke dalam pembelajaran berikut. Pertama, bercerita/ mendongeng. Bercerita tidak hanya kegiatan yang bersifat hiburan, tetapi juga merupakan sarana dalam mengembangkan berbagai pengetahuan. Pendidik dapat mengintegrasikan berbagai konsep, ide, serta tujuan instruksional ke dalam cerita/dongeng yang akan disampaikan. Ketika peserta didik melakukan kegiatan bercerita, akan membantu peserta didik dalam mengembangkan berbagai konsep dan ide di dalam benaknya. Selain itu, kegiatan bercerita juga akan mengembangkan kemampuan berkomunikasi peserta didik.

Kedua, bertukar pikiran/brainstorming. Kegiatan bertukan pikiran akan mengembangkan pola berpikir seseorang menjadi kritis. Seseorang dapat mencurahkan ide dan gagasan yang ada di dalam pikirannya sesuai dengan topik yang dibahas. Strategi ini akan membuat semua peserta didik mengemukakan gagasannya secara orisinal.

Ketiga, rekaman. Rekaman yang berkaitan dengan materi tertentu bisa dimanfaatkan sebagai strategi dalam pembelajaran berbasis kecerdasan linguistik. Rekaman dapat dilakukan menggunakan alat perekam, seperti tape recorder, smartphone, maupun alat perekam lain. Dengan media rekaman, peserta didik akan belajar dalam berkomunikasi, memecahkan masalah, serta mengemukakan gagasannya.

Keempat, jurnal penulisan. Jurnal penulisan bisa diterapkan dalam kegiatan pembelajaran dalam bentuk jurnal pribadi. Kegiatan menulis jurnal pribadi dapat 
digunakan sebagai media dalam melatih kemampaun membuat catatan tertentu. Dalam menuliskan jurnal pribadi, tidak harus berisi tulisan saja, tetapi dapat ditambahkan berbagai unsur lain seperti foto, gambar, data, dan dialog.

Kegiatan pembelajaran yang berbasis kecerdasan verbal linguistik ini penting untuk dilakukan dalam upaya meningkatkan kemampuan mahasiswa dalam menulis artikel ilmiah. Menurut Lwin, dkk. (2008:4), kecerdasan linguistik pada diri seseorang perlu terus dikembangkan karena dapat meningkatkan berbagai kemampuan/kompetensi penting sebagai berikut. Pertama, kecerdasan linguistik dapat meningkatkan kemampuan seseorang dalam membaca. Kedua, kecerdasan linguistik dapat meningkatkan kemampuan seseorang dalam menulis. Ketiga, kecerdasan linguistik dapat meningkatkan keterampilan seseorang dalam mendengarkan. Keempat, kecerdasan linguistik dapat membangun pembawaan diri dan keterampilan linguistik umum.

\section{Simpulan}

Berdasarkan hasil penelitian dan pembahasan di atas, dapat disimpulkan bahwa kemampuan mahasiswa semester II Program Studi Sistem Komputer Unisba Blitar dalam menulis artikel ilmiah dapat ditingkatkan dengan menggunakan strategi pembelajaran berbasis kecerdasan verbal linguistik. Peningkatan kemampuan mahasiswa tersebut dapat dilihat dari segi proses maupun produk hasil pembelajaran. Dari segi proses, peningkatan kemampuan mahasiswa dalam pembelajaran menulis artikel ilmiah terlihat dari peningkatan kualifikasi pembelajaran dengan indikator adanya peningkatan keaktifan dan keantusiasan mahasiswa dari pembelajaran di siklus I ke siklus II. Dari segi produk hasil pembelajaran, peningkatan terlihat pada kualitas produk artikel ilmiah dari siklus I ke siklus II.

Berdasarkan hasil dari penelitian yang telah dilakukan, saran yang bisa diberikan sebagai berikut. Pertama, bagi dosen pengampu mata kuliah, sebaiknya memikirkan secara matang berkaitan dengan penggunaan strategi pembelajaran yang tepat dalam materi menulis artikel ilmiah. Salah satu strategi pembelajaran yang dapat digunakan dalam materi menulis artikel ilmiah adalah strategi 
pembelajaran berbasis kecerdasan verbal linguistik. Strategi pembelajaran ini terbukti dapat digunakan dalam pembelajaran sebagai upaya dosen untuk meningkatkan kemampuan mahasiswa dalam menulis artikel ilmiah. Kedua, bagi peneliti selanjutnya supaya melakukan penelitian tentang menulis artikel ilmiah dengan fokus yang berbeda, misalnya penelitian tentang pengembangan media pembelajaran. Hal ini supaya penelitian terkait dengan menulis artikel ilmiah dapat bervariasi.

\section{Daftar Pustaka}

Amstrong, T. (2013). Kecerdasan Multipel di Dalam Kelas. Jakarta: Indeks.

Blumner, J.S. (2008). Beyond the Reactive: WAC Programs and the Steps Ahead dalam Joumal on Writing Across the Curriculum. Michigan, USA: University of Michigan.

Chatib, M. (2012). Sekolah Anak-anak Juara: Berbasis Kecerdasan Jamak dan Pendidikan Berkeadilan. Bandung: Mizan.

Derish, P. A., Maa, J., Ascher, N. L., \& Harris, H. W. (2007). Enhancing the Mission of Academic Surgery by Promoting Scientific Writing Skills. Journal of Surgical Research, 140(2), 177. doi:10.1016/j.jss.2007.02.018

Halidjah, S. (2015). Peningkatan Keterampilan Menulis Karya IImiah melalui Lesson Study. BAHTERA : Jurnal Pendidikan Bahasa dan Sastra, 14 (1): 47-54. https://doi.org/10.21009/BAHTERA.141.05

Kemmis, S. \& Mc.Taggart, R. (1988). The Action Research Planner. Victoria: Deakin University Press.

Lwin, May, dkk. (2008). How to Multiply Your Child's Intelligence (Cara Mengembangkan Berbagai Komponen Kecerdasan). Yogyakarta: PT Macanan Jaya Cemerlang.

Marselina, S. (2018). Peningkatan Keterampilan Menulis Karya IImiah melalui Strategi Belajar Kooperatif Tipe Group Investigation Siswa Kelas XI MAN I Kota Sungai Penuh. Jurnal Pentas: Jurnal IImiah Pendidikan Bahasa dan Sastra Indonesia, 4 (1):14-21. Retrieved from http://ejurnal.unisda.ac.id/index.php/pentas/article/view/816

Noermanzah, N., Abid, S., \& Septaria, S. (2018). Improving the Ability of Writing a Narrative Charge by Using Animated Images Media Student Class V.B SD Negeri 17 Lubuklinggau. BAHTERA : Jurnal Pendidikan Bahasa dan Sastra, 17(2 Juli), 116. doi:10.21009/bahtera.172.9 
Rijlaarsdam, G., Martine B., Michel C., Tanja J., Mariet R., Elke van S., Anne T., and Huub van den B. (2008). Observation of Peers in Learning to Write. Journal of Writing Research, 1 (1): 53-83. https://doi.org/10.17239/jowr2008.01.01.3

Romli, ASM. (2011). Artikel Ilmiah Populer. Yogyakarta: MMCT.

Wardani, I G. A. K. (2006). Teknik Penulisan Karya Ilmiah. Tangerang Selatan: Universitas Terbuka.

Wiyanto, A. (2008). Terampil Menulis Paragraf. Jakarta: Grasindo.

Zulkarnaini. (2014). Peningkatan Kemampuan Menulis Karya Ilmiah Mahasiswa PGSD Semester I melalui Drill Method". Jurnal Pendidikan Dasar $\begin{array}{lllll}\text { (Jupendas). } \quad 1 & \text { (2): } 1-9 . & \text { Retrieved from }\end{array}$ http://jfkip.umuslim.ac.id/index.php/jupendas/issue/view/20 